\title{
'EUROPE 2020' AND THE EU PUBLIC PROCUREMENT AND STATE AID RULES: GOOD INTENTIONS THAT PAVE A ROAD TO HELL?
}

\author{
Stefan Martinić and Ana Kozina*
}

\begin{abstract}
Summary: In 2010, the European Union launched 'Europe 2020, a strategy for smart, sustainable and inclusive growth' whose goals in employment, innovation, education, social inclusion and climate/energy need to be reached by 2020. Although such a project has undeniable benefits, the authors of this paper analyse the shortcomings of 'Europe 2020' in the field of EU public procurement rules and the latter's interconnected relationship with State aid rules. The paper is divided into two main parts. The first part considers whether social and environmental considerations in a public tender could lead to a violation of the EU's public procurement and/or State aid rules. The paper analyses and presents the possible ways in which social and environmental considerations may lead to discrimination, the prevention of which is one of the basic principles of EU law in general and public procurement rules in particular. Further, the authors analyse the link between public procurement and State aid rules. The second part evaluates the public procurement directives and the La Poste case to find out whether the new directives create new risks of infringing State aid rules. The paper points to the contradictions between public procurement and State aid rules. In doing so, the authors take a critical approach to the new public procurement rules and the difficult task of achieving simplification, flexibility, legal certainty, greater sustainable and inclusive growth while at the same time not jeopardising State aid rules.
\end{abstract}

\section{Introduction}

In February 2016, the largest outlet glacier of the world's largest tropical ice cap retreated, leaving a lake some 86 acres in area and about 60 metres deep. ${ }^{1}$ Carbon dioxide levels in the air are at their highest in

\footnotetext{
* The authors are students at the Faculty of Law of the University of Zagreb. First, we wish to express our thanks and appreciation to our mentor Filip Kuhta who has extended help, guidance and support in the preparation of this paper. Without his help, this paper would not have been possible. Second, we would like to thank the Chair of European Public Law for their creative ideas and suggestions for various sources of information during the European Law Moot Court Competition on the topic of State aid and public procurement which inspired us to write this paper
}

1 NASA, 'Global Climate Change' <http://climate.nasa.gov/> accessed 20 January 2016. 
650,000 years. $^{2}$ The global temperature has risen by $0.8^{\circ}$ Celsius since 1880. Nine of the ten warmest years on record have occurred since $2000 .^{3}$ In 2012, the Arctic summer sea ice shrank to the lowest extent on record. ${ }^{4}$ The global average sea level has risen over the past 100 years and if it continues at this rate it could make the beautiful cities of Amsterdam and Venice an attraction only for fish and divers. The amount of global forest lost between 2000 and 2012 would cover the combined area of Croatia, Belgium, Netherlands, Luxembourg, Germany, Ireland, Slovenia, Austria, France, and Denmark. ${ }^{5}$ In order to change the course of this potentially catastrophic climate trend, the world met in December 2015 in Paris for the United Nations Climate Change Conference.

To make things worse, the planet is not the only thing being hurt. Eurostat estimates that 21.9 million men and women in the EU were unemployed in December 2015. ${ }^{6}$ The youth unemployment rate in the EU in the last quarter of 2015 was $21.4 \%$, while in Croatia, for instance, it was $46.3 \%$ and in Spain it was a staggering $51.7 \% .^{7}$ As the EU economy is still faltering, Eurosceptic and extremist parties in the whole of the EU are on the rise. Most notably, the United Kingdom voted to leave the EU, and Marine Le Pen is promising to organise a referendum on exit from the EU if she is elected President of France in the election in 2017. If both the fifth and sixth largest economies in the world indeed leave the European Union, it will put the whole EU project in jeopardy.

The EU is trying to make a full economic recovery and return to the economic pre-2008 level in order to win popular support at home, while at the same time attempting to be the leader on the world stage in tackling climate change. The goals are big, and there is a plethora of possible means to achieve them. Some are evident and highly advertised, such as the projects 'Europe 2020 strategy for smart, sustainable and inclusive growth'8 and 'Youth Guarantee', ${ }^{9}$ while, for instance, the two public procurement directives, which are also part of the 'Europe 2020' project, are less evident. 
It might come as a surprise that public procurement rules (which are about how public authorities spend public money when buying goods, works or services) are a valuable tool for the EU in achieving its goals. However, these rules have a significant financial impact because they range from buying IT equipment or providing water, gas and electricity to building hospitals or roads. Directive 2014/24/EU of 26 February 2014 on public procurement ${ }^{10}$ and Directive 2014/25/EU of 26 February 2014 on procurement by entities operating in the water, energy, transport and postal services sectors ${ }^{11}$ play a key role in the 'Europe 2020 strategy for smart, sustainable and inclusive growth', as one of the market-based instruments to be used to achieve smart, sustainable and inclusive growth while ensuring the most efficient use of public funds. ${ }^{12}$ They were enacted in order to increase the efficiency of public spending, facilitating in particular the participation of small and medium-sized enterprises (SMEs) in public procurement and to enable procurers to make better use of public money in support of common societal goals. ${ }^{13}$

Public procurement affects a substantial share of world trade flows, amounting to EUR 1,000 billion per year; it makes up a significant part of national economies, adding up to $10-25 \%$ of gross domestic product (GDP). ${ }^{14}$ In the EU, the public purchase of goods and services has been estimated to account for $16 \%$ of GDP. ${ }^{15}$ For instance, in Croatia the public purchase of goods and services amounts to about HRK 40 billion per year, which is almost a third of the State's budget. ${ }^{16}$ As one Commission official put it: 'you aren't buying pencils'. ${ }^{17}$ Since the State is buying with

10 Directive 2014/24/EU of the European Parliament and of the Council of 26 February 2014 on public procurement and repealing Directive 2004/18/EC (Text with EEA relevance) [2014] OJ L94/65 (Directive 2014/24/EU).

11 Directive 2014/25/EU of the European Parliament and of the Council of 26 February 2014 on procurement by entities operating in the water, energy, transport and postal services sectors and repealing Directive 2004/17/EC (Text with EEA relevance) [2014] OJ L 94/243. The paper will concentrate more on the General Directive 2014/24/EU than on the Utilities Directive 2014/25/EU due to the general nature of Directive 2014/24/EU and since for the purpose of this paper the differences between the General and the Utilities Directive are not important.

12 Recital to Directive 2014/25/EU of the European Parliament and of the Council of 26 February 2014 on procurement by entities operating in the water, energy, transport and postal services sectors and repealing Directive 2004/17/EC (Text with EEA relevance) [2014] OJ L 94/243 (Directive 2014/25/EU), para 4.

13 Recital to Directive 2014/25/EU, para 4.

14 For more details, see: European Commission, 'Public Procurement' < http://ec.europa. $\mathrm{eu} /$ trade/policy/accessing-markets/public-procurement/> accessed 24 April 2015.

15 ibid.

16 HRT vijesti, 'Zamjerka javnoj nabavi: Nije najjeftinije uvijek najbolje' (HRT, 17 March 2015) <http:/ /vijesti.hrt.hr/276643/tvrtke-imaju-zamjerki-na-sustav-javne-nabave-ponajvise-na-kriterij-najnize-cijene-23> accessed 25 April 2015.

17 Dylan M Hughes, 'The Inter Relationship between the European State Aid and Public Procurement Rules: When Does a Government Contractor Gain an "Economic Advantage"?' (2009) EIPA 1, 5. 
the public purse, it should always aim to achieve the best value for money and, at the same time, it should foster social justice and protection of the environment.

Unfortunately, in spite of a noble goal and potent means, there might still be negative consequences. Hence, questions should be asked about whether the implementation of the 'Europe 2020 strategy for smart, sustainable and inclusive growth' in the public procurement rules has gone too far and whether it has led to unwanted consequences coming from both the MSs' and the EU's legislation in the field of public procurement and State aid. In other words, do these good intentions lay a road to hell? This could lead to a metaphorical hell if the implementation of the 'Europe 2020' goals in the public procurement rules undermine the basic principle of non-discrimination and the rules of State aid.

The original rationale for imposing EU oversight on State aid was to prevent countries from deliberately using State aid to benefit their own enterprises at the expense of rivals located in other Member States. ${ }^{18}$ If a country subsidises national producers of goods for which there is international trade, similar subsidies may be granted in retaliation by other countries, which in turn creates an escalation of subsidies and sets off a potentially wasteful subsidy race. ${ }^{19}$ Moreover, State aid may distort the dynamics of the competitive process; aid may help perpetuate failed business models; it may reduce the incentive to compete; and may create moral hazard by encouraging excessive risk taking. ${ }^{20}$ These effects are likely to be even more serious and long lasting than having an uneven playing field. In particular, moral hazard is a key concern. ${ }^{21}$ An implicit promise of future aid may affect firms' incentives by protecting them from the adverse consequences of their risk-taking, thereby fostering overly risky behaviour. ${ }^{22}$ Repeated State aid may eventually create the expectation that certain undertakings are 'too big to fail' (or too politically important to fail), and thus perpetuate overly risky or inefficient business practice. ${ }^{23}$ Therefore, State aid rules are valuable for the European Union, so any environmental, societal or any other gain should not be offset by jeopardising the goals of State aid rules.

Due to the relevance of the project 'Europe 2020', public procurement and State aid rules, this paper will analyse the following main question: What are the shortcomings of the implementation of 'Europe 2020'

\footnotetext{
18 Kelyn Bacon, European Union Law of State Aid (2nd edn, OUP 2013) 9.

19 ibid.

20 ibid.

21 ibid.

22 ibid.

23 ibid.
} 
in the field of EU public procurement rules and in the latter's relationship with EU State aid rules?

In order to answer the main question, the paper will analyse: a) the effects of the project 'Europe 2020' in the domain of public procurement and State aid rules; b) the possible ways in which an MS can misuse the project's goals to the detriment of public procurement and State aid rules; and c) the possible risk to State aid rules from the new public procurement directives.

The paper is divided into two main parts. The first part analyses the social and environmental considerations in public tenders which were brought to the attention of contracting authorities through the project 'Europe 2020'. The authors consider whether social and environmental considerations in public tenders can lead to a violation of the EU's public procurement and/or State aid rules. The paper analyses and presents possible ways in which social and environmental considerations can lead to discrimination, the prevention of which is one of the basic principles of EU law in general and public procurement rules in particular. Further, the authors consider whether the link between public procurement and State aid rules has changed due to the implementation of 'Europe 2020'.

The second part of the paper evaluates the new public procurement directives and the La Poste case ${ }^{24}$ in order to find out whether the new directives create new risks of infringing State aid rules. The authors point out the contradictions between public procurement and State aid rules. In doing so, they take a critical approach to the new public procurement rules and their difficult task of achieving simplification, flexibility, legal certainty, greater sustainable and inclusive growth while at the same time not jeopardising the valuable goals of State aid rules.

\section{Social and environmental considerations in a public tender - a double-edged sword?}

This section analyses the social and environmental considerations in public tenders that were brought to the attention of contracting authorities through the project 'Europe 2020'. The authors consider whether the social and environmental considerations in public tenders lead to a violation of EU public procurement and/or State aid rules.

First, the section describes in what ways social and environmental considerations can be manifested in public tenders. Second, it evaluates

24 Case C-559/12 P French Republic v European Commission ECLI:EU:C:2014:217; Alessandro Nucara and Edoardo Gambaro, 'The La Poste Case: A Guaranteed EPIC Battle' (2013) 3 ESTAL 568-574; Valerie Guigue Koeppen, 'La Poste: Implied Unlimited State Guarantees Under the Loop of State Aid Law' (2014) 5 JECLP 546-548. 
whether social and environmental considerations in a public tender can lead to discrimination. Third, it clarifies how disguised discrimination violates public procurement rules, and, finally, it demonstrates how a violation of public procurement rules can lead to a violation of State aid rules.

\subsection{Manifestations of social and environmental considerations}

One of the principles of EU public procurement is the compliance of performance with obligations in the fields of environmental, social and labour law established by the Union, national law, collective agreements or by international law. ${ }^{25}$ But, irrespective of the new directives and the push of 'Europe 2020', contracting authorities have always been encouraged and have always been keen to introduce environmental and social considerations above minimum compliance into their purchases. This could be done through various stages of procurement procedures.

The first way in which environmental and social considerations can be implemented is through technical specifications. As previously mentioned, they lay down the characteristics of a public works contract, and the services or supplies that are being procured. ${ }^{26}$ According to the directive, it is allowed to specify 'environmental and climate performance levels ${ }^{27}$ of a material and product in general, as well as of production methods and the process in any stage of the life cycle, ${ }^{28}$ as long as those requirements are related to the subject matter and are proportionate to its value and objectives. ${ }^{29}$ This means that, for example, a contracting authority may demand that the energy supplied comes from renewable sources, that paper is $100 \%$ recycled or that the food is grown by using organic methods. ${ }^{30}$ Social concerns are explicitly mentioned, demanding that technical specifications for products should be 'drawn up so as

\footnotetext{
25 Directive 2014/24/EU, art 18.

26 It is necessary to emphasise that the required characteristics need to refer to the subject matter of the contract, not to the general policy or qualities of the operator. Directive 2014/24/EU, annex VII.

27 ibid.

28 "Life cycle" means all consecutive and/or interlinked stages, including research and development to be carried out, production, trading and its conditions, transport, use and maintenance, throughout the existence of the product or the works or the provision of the service, from raw material acquisition or generation of resources to disposal, clearance and end of service or utilisation' Directive 2014/24/EU, art 2 indent 20.

29 Directive 2014/24/EU, art 42(1).

30 For example, in 2010, the Estonian Environment Ministry tendered for cleaning services and in the technical specifications demanded that all plastic bags be biodegradable, and that the waste be sorted (packaging, organic waste, etc); in Malta, the national body responsible for schools required that a new school building be energy self-sufficient. See European Commission, 'Buying Green! A Handbook on Green Public Procurement' (2nd edn, Publications Office of the European Union 2011) 25, 27. For more on sustainable procurement, see Martin Trybus, Roberto Caranta and Gunilla Edelstam EU Public Contract Law: Public Procurement and Beyond (3rd edn, Bruylant 2014).
} 
to take into account accessibility criteria for persons with disabilities or design for all users'. ${ }^{31}$ In the process and production methods, 'socially aware' technical requirements may be set in order to protect the health and safety of workers, demanding a certain way of handling dangerous products or measures to avoid accidents at work. ${ }^{32}$

Contrary to the technical specifications (and award criteria), concerned with and restricted solely to the goods, service or work procured, the criteria for qualitative selection covers aspects related to economic operators, ie the tenderers-to-be. These criteria manifest themselves in two ways. First, they manifest themselves as exclusion grounds, according to which it is possible to exclude companies in breach of environmental, social and labour obligations established by Union, national or international law. ${ }^{33}$ The second manifestation is selection criteria regarding the technical and professional ability to execute the contract. Contracting authorities may require - but only where the qualities of a tenderer are important for carrying out a contract - proof of the necessary human and technical resources, educational or professional qualifications of the staff, previous experience, etc. ${ }^{34}$

Finally, the contract is to be awarded for the most economically advantageous tender. The basis of identifying this can be the price or cost, usually including the best price-quality ratio in assessing the submitted tenders. Environmental and/or social aspects can also be taken as award criteria helping to specify this ratio but again they need to be strictly related to the subject matter of the contract, not to the general policy of the economic operator. ${ }^{35}$ The difference from the technical specifications that define the minimum level of performance required is that the contracting authority may decide to grant extra points to those tenders that are better with regard to these aspects at the award stage. ${ }^{36}$

Nevertheless, in applying these criteria, the contracting authority does not have unrestricted freedom of choice. The criteria need to be adequately specific and objectively quantifiable, and they need to be expressly mentioned in the contract notice or at least in tender docu-

\footnotetext{
31 Directive 2014/24/EU, art 42(1).

32 European Commission, 'Buying Social! A Guide to Taking Account of Social Considerations in Public Procurement' (Publications Office of the European Union 2010) 29.

33 This also applies when the breaching of environmental law and social provisions constitutes grave professional misconduct according to national legislation and when a tenderer has been found guilty of not complying with national rules regarding health and safety at work or prohibiting discrimination on any ground. Directive 2014/24/EU, art 57(4).

34 Directive 2014/24/EU, art 58(4).

35 Directive 2014/24/EU, art 67(2).

36 European Commission (n 32) 37.
} 
ments. ${ }^{37}$ Of course, they need to comply with the fundamental principles of EU law, especially with the principle of non-discrimination, from which derive other provisions, such as the freedom to provide services and the freedom of establishment. ${ }^{38}$

When the contracting authority wishes to achieve additional environmental and social goals, separate from those expressed in the technical specifications or in the award criteria, it can use contract performance clauses. For example, these might include encouraging the employment of persons with disabilities, or the long-term unemployed, or giving preference to environmentally responsible delivery and disposal of the packaging of goods. ${ }^{39}$ They specify how a contract must be carried out, which means that these demands must relate to the tasks necessary for the performance of the contract. ${ }^{40}$ Companies must be aware of the obligations they will need to comply with, so contract performance clauses must be 'indicated in the call for competition or in the procurement documents', ${ }^{41}$ even though compliance with them should be monitored only during the execution of the contract. ${ }^{42}$ They always need to comply with national and EU law, and may never lead to the unequal treatment of tenderers.

\subsection{Possible discrimination in the social and environmental considerations}

Public procurement procedures through which governments and the public sector acquire needed goods, works and services can be used to promote certain policies. ${ }^{43}$ Boosting the employment of disadvantaged groups, promoting equality, and protecting the environment (or favouring domestic industry) while purchasing goods, works and services kill two birds with one stone. Still, while these practices are encouraged - which is visible now more than ever in the reform of the general and utilities directives as part of the 'Europe 2020' strategy - it has to be ensured that the fundamental principles of EU law are respected. Therefore, the prin-

37 Case C513/99 Concordia Bus Finland Oy Abv Helsingin kaupunki EU:C:2002:495, para 66.

38 ibid, para 63.

39 European Commission (n 32) 44.

40 Directive 2014/24/EU, art 70.

41 ibid.

42 European Commission, 'Buying Green! A Handbook on Green Public Procurement' (2nd edn, Publications Office of the European Union 2011) 46.

43 The attitude of the Commission and the Court towards implementing various policies in the procurement process has changed over time. After initial tolerance up to the mid 1980s, a shift occurred, led by efforts to build a strong single market. In the mid 1990s, the use of environmentally and socially responsible policies in public procurement made a great comeback, receiving (not without some criticism) more and more encouragement lasting until today. Christopher McCrudden, 'Buying Equality' (2009) 8 European AntiDiscrimination Law Review 21. 
ciple of non-discrimination, freedom of establishment and the freedom to provide services are invoked multiple times in the legislation and in the judgments of the Court. ${ }^{44}$

Often in the form of indirect discrimination, ${ }^{45}$ contracting authorities may (intentionally or unintentionally) breach fundamental principles of EU law by imposing certain government policies. An example of how social and environmental considerations can lead to discrimination is well illustrated in two landmark cases: Beentjes and Concordia Bus.

In the Beentjes case, ${ }^{46}$ a tender by Gebroeders Beentjes BV had been rejected by the Netherlands Ministry of Agriculture and Fisheries because it appeared less acceptable than that of the next lowest bidder. The awarding authority stated that Beentjes lacked sufficient specific experience, and that it 'did not seem to be in a position to employ long-term unemployed persons'. ${ }^{47}$

In proceedings before the Court, a few things were clarified. Namely, (a) what characterises a body to be classified as a part of the State; (b) the criterion of 'specific experience' is a legitimate aspect of technical ability and knowledge; (c) a contracting authority may apply the criterion of the most acceptable tender' if it reflects its right to discretion but may not involve arbitrary choice; and (d) social conditions may be taken into account if they do not have a discriminatory effect on tenderers from other MSs. ${ }^{48}$

While allowing the promotion of employment of those from 'disadvantaged' groups by applying the criterion of employing long-term unemployed persons, the Court set some boundaries. It dismissed the application of this condition as a selection criterion, as well as an award criterion, on the ground that it bore no relation to the contractors' economical/financial/technical suitability and ability. ${ }^{49}$ It enabled its use as a contract performance clause, as a means of attaining a goal not related to the specifications of a procured good, insofar as it is compatible with the provisions of EU law, in particular, the right of establishment and the

\footnotetext{
44 See Cases C31/87 Beentjes $v$ Netherlands EU:C:1988:422; Concordia (n 37); C3/88 Commission v Italy (Data-processing contracts) EU:C:1989:606; C175/88 Biehl EU:C:1990:186; C330/91 Commerzbank EU:C:1993:303.

45 Direct discrimination occurs when one subject is treated less favourably than another in a comparable situation, and indirect discrimination occurs when an apparently neutral provision, criterion or practice has the effect of disadvantaging a higher percentage of persons who share protected characteristics (ethnicity, sex, religion, etc). Paul Craig and Grainee de Burca, EU Law: Text, Cases, and Materials (5th edn, OUP 2011) 896.

46 Beentjes (n 44).

47 ibid, para 5.

48 ibid, paras $1-2$.

49 ibid, para 28.
} 
right to provide services. ${ }^{50}$ The Court acknowledged that the obligation to employ long-term unemployed persons may infringe on the prohibition of discrimination on grounds of nationality ${ }^{51}$ if it became obvious that such a condition favours tenderers from the MS concerned, or can be satisfied only by them. ${ }^{52}$ Following the Court's reasoning, the current authors believe that these kinds of clauses in reality represent disguised, indirect discrimination of entrepreneurs who have an interest in responding to the public tender, and direct discrimination of workers. On the other hand, such discrimination could be justified by the lack of a common EU social policy and as any other discriminatory measure with a proper justification which is already recognised in EU law.

The authors believe that these kinds of clauses can lead to indirect discrimination of entrepreneurs who have an interest in responding to a public tender and direct discrimination of workers because, when trying to enhance employment, the contracting authorities often target what the authors of this paper call 'disadvantaged' groups. They include young people without work experience, the long-term unemployed, persons with disabilities, etc. The problem lies in their prior usually very low, or nonexistent, income. ${ }^{53}$

Residents who are usually nationals of the Member State in which the public procurement takes place have a considerable advantage in comparison to persons who do not have residence in that MS. An advantage exists because residents have already situated themselves and manage to cover their costs of living on a longer and a regular basis. In contrast, the average long-term unemployed person who would need to move to another State or travel each day to work would have to assume these costs at short notice. The disadvantage is all the greater for non-residents of that MS if it is taken into account that there are more costs during the process of travelling or moving and adapting to a new residence. For instance, a long-term unemployed resident of a MS in which there is a public tender already has a place to stay and is able to pay the regular costs of living, while a long-term unemployed person from another MS would have to find residence and buy essential items.

\footnotetext{
50 ibid, para 29.

51 Consolidated version of the Treaty on the Functioning of the European Union [2012] OJ C-326/47 (TFEU), art 18.

52 Beentjes (n 44) para 30.

53 In Beentjes the problem arose because of the requirement that the long term unemployed should be registered with the local employment service', but the question of indirect discrimination on grounds of nationality was posed, because the long term unemployed from other countries were not likely to be registered in Holland'. The Court left the national court to decide if this was the case. See Beentjes (n 44). Since, those persons are long-term unemployed, it is in principle harder to expect them to have the financial assets to move to a different MS.
} 
Even if the company considered paying some of the expenses of its workers who would need to move or travel, this would raise its overall costs and would automatically mean that it would have to increase its price. Therefore, the company would be motivated either to employ residents of that MS or else risk losing the tender on account of the higher price it would have to offer.

As a counterargument, it could be said that every person has the same living expenses regardless of their nationality or financial status at a certain time in one MS; therefore, there is no possibility of discrimination because the living costs are equal for residents and foreigners. Furthermore, the proponents of such a claim could argue that there is no difference between 'regular' workers and long-term unemployed workers because for both there is the same difficulty of travelling or moving to a different MS. The fact that there are greater costs for foreign companies and foreign workers is something that should not be regarded as discrimination. Moreover, if a foreign company moves to a different MS, it will provide equal compensation of the additional expenses of working abroad for 'regular' workers and long-term unemployed workers.

While this might be true, differences in prior life conditions cannot be neglected, especially in the situation where the groups in question have a limited budget. If the residents already have housing and can pay their regular living costs, they are in a better position to apply for the job than people living in other MSs. Therefore, such a requirement for employing long-term unemployed people is de facto discrimination because it provides for a larger number of people employed from the MS in which there is a public tender. If there were no such requirement, regular workers from other MSs would have a better chance to be employed because they have on average more financial assets needed for moving or travelling to another MS than the long-term unemployed.

However, this discussion can also be approached from a different standpoint. An argument can be made in the sense that since the EU does not have a common social policy and since it has quite limited competences in this field, there is no reason why the condition of employing disadvantaged groups of people could not be limited to nationals of the MS concerned, as social goals are usually national ones.

Ruth Nielsen holds that the Court in the Beentjes case observed only possible discriminatory effects on the tenderers from the other MSs, and thus indirect violation of article 56 TFEU on freedom to provide services, but comments that indirect violation of article 45 TFEU on free movement of workers may also come into question. ${ }^{54}$ The authors welcome

54 Ruth Nielsen, 'Discrimination and Equality in Public Procurement' < http:/ / arbetsratt.juridicum.su.se/Filer/PDF/klaw46/discrimination.procurement.pdf> accessed 12 May 2015. 
this reasoning made within the boundaries of the facts of the Beentjes case. ${ }^{55}$ They claim that in general this may be true, but that in the above example there is only hindrance to the freedom to provide services. When there is a contract performance clause requiring the employment of longterm unemployed people,${ }^{56}$ the effect does not impede the participation of tenderers from other States, but favours the long-term unemployed from the State in question. The cost to fulfil a tender for a foreign economic operator willing to employ residents will be the same as for a domestic economic operator, so competitive conditions for them are the same. Those who are impacted and favoured are residents of the State where the public procurement is conducted, because long-term unemployed persons from other MSs are less likely to move due to financial restraints. Thus, by indirect discrimination there is an infringement of article 56 TFEU on the freedom to provide services.

Another major concern for MSs and the EU is preserving the environment. Reckless industrialisation has turned into a drive for sustainable development. Introducing Green Public Procurement (hereinafter: GPP) into national legislations is yet another way of putting environmental concerns into government policies. It is defined by the European Commission's Communication as 'a process whereby public authorities seek to procure goods, services and works with a reduced environmental impact throughout their life-cycle ${ }^{57}$ compared to those with the same primary function that would otherwise be procured. However, besides undeniable benefits, these kinds of practices have from the very start raised the question of discrimination as well.

In 1997 the Purchasing Unit of the City of Helsinki called for tenders to operate the urban bus network within the city. After a dispute initiated by an unsuccessful tenderer in the landmark case Concordia Bus, ${ }^{58}$ the Court clarified what environmental requirements as one of the award criteria should look like in order to be compatible with the Treaties and public procurement directives and stressed the necessity of a link to the subject-matter'. 59

Concordia Bus made an application arguing that the award of additional points to a fleet with nitrogen oxide emissions and noise levels

\footnotetext{
55 Namely, registration of the long-term unemployed with the local employment service.

56 No matter whether this is at a certain fixed percentage or in the form of awarding higher points to a tenderer that can offer more places for such persons.

57 Communication from the Commission to the European Parliament, the Council, the European Economic and Social Committee and the Committee of the Regions, 'Public Procurement for a Better Environment' (2008) 400, 4.

58 Concordia (n 37).

59 For an example of the opposite situation, where the Court stated the absence of a link, see Case C448/01 EVN AG \& Wienstrom GmbH v Austria EU:C:2003:651.
} 
below certain limits was unfair and discriminatory'. ${ }^{60}$ They found it discriminatory that the highest standards for the required bus types could be reached only by one tenderer, HKL, which was in fact part of the transport department of the city of Helsinki. ${ }^{61}$

The Court first stated that combating the pollution effects, ie the externalities of the procured good, is linked to the subject matter. ${ }^{62} \mathrm{Sec}-$ ond, the contracting authority may pose 'environmental' award criteria, provided that they are linked to the subject matter, that they do not confer an unrestricted freedom of choice on the authority, that they are expressly mentioned in the contract documents or the tender notice, and that they comply with the fundamental principles of EU law, in particular the principle of non-discrimination. ${ }^{63}$ And third, after establishing that all the requirements were complied with, it addressed specifically the last one, saying that 'the fact that one of the criteria adopted by the contracting entity (...) could be satisfied only by a small number of undertakings, one of which was an undertaking belonging to the contracting entity', ${ }^{4}$ does not constitute a breach of the principle of equal treatment.

The authors believe that the introduction of 'green' award criteria can be used as a tool for disguised discrimination, even though this seemingly complies with all the legal requirements. It can also be used for fixing the technical specifications or criteria, especially if there are complementary policies in the tax law and in the public procurement of one MS.

In a situation like this, when the contracting authorities' demands can be met only by a handful of operators (naturally, provided the competition is not artificially narrowed down), ${ }^{65}$ there is no question of discrimination, but just that the goods on the market have different characteristics and qualities. The purchaser has every right to choose what suits him best, regardless of the number of tenderers. But when the goods of the required characteristics are available for each operator under different conditions, they have the effect of increasing the costs for the tenderer and consequently of his offered price. For example, there could be a requirement that the tenderers need to have at least $25 \%$ of electrically powered vehicles in order to apply for the public tender. Some countries have various tax reductions, incentives, favourable credit terms and interest rates or shorter write-off periods applicable to or offered to compa-

Concordia (n 37) para 27.

61 ibid.

62 ibid, paras 53-57.

63 ibid, para 64.

64 ibid, para 85.

65 ibid, para 85. 
nies buying environmentally friendly goods or pursuing environmentally conscious practices in general. While this is praiseworthy in itself, in public procurement processes it may create unjustifiable discrimination among tenderers from different MSs.

For example, if the purchase of electric vehicles is subject to favourable terms in one MS in comparison to the purchase of the same vehicles in another, a company in the former MS would have fewer expenses than one in the latter. The company that has more expenses will be forced to raise its offered price for the public tender in order to have a profitable business. If the use, ownership, service (or anything similar) of electric vehicles is required by a contracting authority, tenderers from different States would be in an unequal position with regard to their offered price in the public procurement procedure. Such a difference in the offered price would merely be the result of the different location of their headquarters. Unfortunately, the offered price of the submitted tenders may considerably affect the decision of the authorities.

To explain this point, the authors make a hypothesis that there is a public tender in Bratislava in which the contracting authority inserts a green clause. Let us say that Slovakia has a tax reduction for environmental investments. This would mean that every company based in Slovakia would be in a better position than a company based in Austria. The cost of the needed investments would be smaller for Slovak undertakings than for their Austrian competitors. In the opinion of the authors, such a green requirement may be used as a tool for disguised discrimination which is even more problematic if the MS does not usually have similar environmental considerations in different aspects of its legal system. In such a case, the motivation of the contracting authority becomes dubious.

Proponents of this measure can argue that there cannot be disguised discrimination because such a situation is only the result of regulatory differences within the EU. Moreover, they argue that every MS has sovereignty to determine its own tax system. In the Salzgitter case, ${ }^{66}$ the Court stated that due to the absence of Community-level harmonisation of the tax provisions of the MSs, such an approach was not meaningful, because it would in effect 'compare different factual and legal situations arising from legislative and regulatory disparities between the MSs'. ${ }^{67}$ The authors believe that this argument does not hold since the problem in this hypothetical case lies not in the tax system itself, but in the design of the tender which a State may use in its favour or for disguised discrimination in order to favour one tenderer over another.

\footnotetext{
66 Case T308/00 Salzgitter $v$ Commission EU:T:2004:199.

67 ibid, para 81.
} 
The authors stress that by (mis)using positive legislation in a public procurement procedure by seemingly neutral requirements, the State can create a discriminatory effect. The problem lies not in the positive legislation or in the regulatory differences within the EU, but arises if a public tender is designed to favour one party. The authors' message is that social and environmental clauses can be misused as disguised discrimination, so the inclusion of such clauses should be examined. If there is any doubt of foul play, all the facts of the case at hand need to be analysed to find out if the social and environmental clauses were used for their primary aim or if they were misused for disguised discrimination or to unduly favour one tenderer. ${ }^{68}$

\subsection{Violation of public procurement rules}

The preceding sections have shown how introducing environmental and social considerations can lead to restrictions of fundamental freedoms as special expressions of the principle of non-discrimination. In the following parts, the authors show how contravening the basic provisions of EU law directly breaches public procurement rules, and how violating the latter leads to State aid incompatible with the internal market.

Paragraph 1 of the Recital to the 2014/24 Directive states that the award of public contracts has to comply with the principles of the TFEU, and that the awarding of public procurement contracts above certain thresholds has to comply with the provisions of the directives in order to ensure 'that those principles are given practical effect and public procurement is opened up to competition'. ${ }^{69}$ Article 18 of the 2014/24 Directive repeats the prohibition of discrimination. ${ }^{70}$ The situations presented in this paper constitute a considerable risk of unequal treatment, thus breaching both sets of rules.

The authors' aim is not to claim that environmental and social concerns are an a priori breeding ground for States' intentional or unintentional violation of various rules applicable within the EU. Rather, the aim is to warn that all agendas present in government actions need to be scrutinised, regardless of their undoubtedly valuable core idea. Such scrutiny is necessary because sometimes there can be malicious motivation, but also sometimes MSs go down a road paved with good intentions, but could find themselves in a metaphorical hell.

\footnotetext{
68 Although a comprehensive analysis is beyond the scope of this paper, one of the relevant factors in deciding if social and environmental clauses are used for their primary aim or if they are misused for disguised discrimination or for unduly favouring one tenderer could be to assess if social and environmental clauses tend to favour tenderers or nationals from one MS instead of another.

69 Recital to Directive 2014/24/EU, para 1.

70 ibid.
} 


\subsection{The relationship between $E U$ public procurement and State aid rules}

An understanding of such a relationship is needed so that an analysis can be made on whether there is a possible risk to State aid rules from the new public procurement directives under the influence of the 'Europe 2020 ' project. It is also important to be aware of occasional interdependence between EU public procurement and State aid rules in order to be able to better scrutinise whether the new public procurement directives change the nature of the relationship between EU public procurement and State aid rules.

State aid rules are included primarily in the Treaty on the Functioning of the EU, ${ }^{71}$ but are also dealt with in different sources of soft law, such as guidelines, notices, etc. Public procurement rules, even though affected by the general provisions of the TFEU, such as those on nondiscrimination and transparency, are included in the Public and Utilities Procurement Directives. State aid rules see the State as an investor or creditor, and public procurement rules see it as a purchaser of goods, works or services. ${ }^{72}$ In both cases, however, the State needs to satisfy the 'market economy investor/creditor/purchaser principle', ie it needs to behave as a private economic operator seeking just return and profit, or as a private consumer trying to strike the best possible price-quality balance. So, the logical conclusion would be that if a State does not hit the right balance (or the lowest price/highest quality extreme if it so decides) in its acquisitions, there is a risk that an unfair economic advantage will be given to the awarded provider of goods, works or services. In this situation, from the side of the State, we (may) have an infringement of public procurement rules, and, on the side of the State's supplier, we (may) have an infringement of State aid rules. ${ }^{73}$

An analysis of previous academic papers, the case law of the Court, and the Commission's Reports on this matter shows how indeed a breach of procurement rules may lead to a breach of State aid rules.

\subsubsection{The acid test}

In the overview of the basics of State aid, it was stated that four cumulative conditions need to be satisfied for a certain measure to be characterised as State aid - intervention by the State or through State resources, advantage on a selective basis, distortion or a threat to dis-

\footnotetext{
71 Arts 107, 108 and 109 TFEU.

72 Andreas Bartosch, 'The Relationship Between Public Procurement and State Aid Surveillance: The Toughest Standard Applies?' (2002) 39 CML Rev 551, 552.

73 Phedon Nicolaides and Sarah Schoenmaekers, 'Public Procurement, Public Private Partnerships and State Aid Rules: A Symbiotic Relationship' (2014) 9(1) European Procurement \& Public Private Partnership Law Review 50, 50.
} 
tort competition, and likeliness to affect intra-EU trade. The definition of public procurement explains that the public sector purchases goods, works and services through a competition held on an EU internal market by awarding a public contract to one or several operators. When these 'definitions' are combined, three out of four of them will usually be met in each public procurement. Since contracting authorities are State entities and bodies governed by public law dependent on a State, most public contracts will be imputable to the State and financed by the State's resources. ${ }^{74}$ By awarding a contract only to the winning tenderer or a group of them, the condition of selectivity will obviously be met. ${ }^{75}$ And leaning on that condition, the bigger the value of the contract, the greater is the chance of distorting competition and affecting trade between the MSs. ${ }^{76}$ The condition that raises most doubts is the economic advantage that would not have been obtained under normal market conditions, ie the question of whether the State behaved and made its final choice according to the Market Economy Investor (buyer) Principle. ${ }^{77}$

There are roughly three ways in which a State can fail to act as a private consumer. ${ }^{78}$ When it pays more than the market price for a certain good, work or service, ${ }^{79}$ when it excludes suppliers (who may or may not be cheaper or better) from the procedure, ${ }^{80}$ and when it settles a contract by which it buys large quantities of something it does not really need. ${ }^{81}$

Taking all this into consideration, and based on the vast case law of the Court, the Commission stated in its decision in the London Underground Public-Private Partnership case that:

\footnotetext{
74 Albert Sánchez-Graells, 'Public Procurement and State Aid: Reopening the Debate?' (2012) 21(6) Public Procurement Law Review.

75 See generally on this, Bartłomiej Kurcz and Dimitri Vallindas, 'Can General Measures Be ... Selective? Some Thoughts on the Interpretation of a State Aid Definition' (2008) 45 CML Rev 159.

76 Richard Burnley, 'Interstate Trade Revisited: The Jurisdictional Criterion for Articles 81 and 82 EC' (2002) 23(5) European Competition Law Review 217; for a detailed analysis of potential competition distortions generated by the public buyer, see Albert Sánchez-Graells, 'Distortions of Competition Generated by the Public (Power) Buyer: A Perceived Gap in EC Competition Law and Proposals to Bridge It' (2009) The University of Oxford Centre for Competition Law and Policy Working Paper CCLP (L) 23, 3-17. The Court has often stated that even relatively little aid and the relatively small size of the undertaking do not exclude the possibility that intra-EU trade may be affected. See Case 142/87 Belgium v Commission EU:C:1990:125, para 43; Joined Cases C278/92, C279/92 and C280/92 Spain v Commission EU:C:1994:325, paras 40 - 42.

77 Case T14/96 BAI $v$ Commission EU:T:1999:12, paras 71-76; Sánchez-Graells (n 74); Bartosch (n 72) 551.

78 Nicolaides and Schoenmaekers (n 73) 52.

79 Case C239/09 Seydaland Vereinigte Agrarbetriebe $v$ BVVG Bodenverwertungs EU:C:2010:778, para 34; C290/07 Commission v Scott EU:C:2010:480,para 68.

80 Nicolaides and Schoenmaekers (n 73) 52.

81 ibid; $B A I$ (n 77).
} 
After the observance of an open, transparent and non-discriminatory procedure, it is, in principle, presumed that the level of any market sector support can be regarded as representing the market price for the execution of the project. This conclusion should lead to the assumption that, in principle, no State aid is involved. ${ }^{82}$

In its assessment of the famous Welsh Public Sector Network Scheme case, the Commission once again clarified a rebuttable presumption that no State aid incompatible with the TFEU provisions exists where the award of the contract is:

a) a pure procurement transaction; 83 and

b) the procurement procedure is compliant with the EU public procurement directives and suitable for achieving best value for money - inasmuch as no economic advantage which would go beyond normal market conditions will usually arise under these circumstances. ${ }^{84}$

To put it simply, determining whether the contract was awarded according to the public procurement rules is an acid test ${ }^{85}$ to determine whether there is undue economic advantage, ie State aid granted.

Still, not every situation has a public procurement - State aid parallel. In certain cases, the affected subject may not be concerned with one of these rules. For example, the State aid case in which Ireland gave illegal tax benefits to Apple worth up to $€ 13$ billion was not concerned with public procurement rules. The case was mostly about State aid rules and tax rules. ${ }^{86}$

Examining the possible discriminatory impact of social clauses in a tender, the authors establish that indirect discrimination might breach article 56 TFEU on the freedom to provide services. But, from the perspective of the State aid rules, article 107(1) generally does not apply to benefits to individuals, ie natural persons. ${ }^{87}$ In a situation where the di-

82 Decision in the Case N264/2002 London Underground Public Private Partnerships, para 79.

83 On purchasing services from the market in order to satisfy a clearly defined public sector need, see Hughes (n 17) 5.

84 Assessment of the Commission of 30 May 2007, in Case N46/2007 Welsh Public Sector Network Scheme [C(2007) 2212 final]. For a short outline, see Nora Tosics and Norbert Gaal, 'Public Procurement and State Aid Control: The Issue of Economic Advantage' (2007) European Commission, Competition Policy Newsletter 3, 16-17.

85 Sànchez-Graells (n 74) 10.

86 See more: European Commission, Press release, 'State Aid: Ireland Gave Illegal Tax Benefits to Apple Worth up to $€ 13$ billion' < http://europa.eu/rapid/press-release_IP-16-2923_ en.htm> accessed 9 October 2016.

87 See eg the Decision in Case N142/2005 Low Carbon Car Grant Programme; Bacon (n 18) 28. 
rect beneficiaries are individuals, State aid may come into question only if that measure procures an indirect advantage to specific undertakings. ${ }^{88}$

Favourising residents of a certain State does not benefit particular tenderers, because their access to competition is unchanged, as are their chances. From the perspective of the undertakings, the competition is not distorted, so there is no State aid in this situation either. When the public procurement procedure is compliant with the provisions of the Directive, there is a presumption that no State aid incompatible with the internal market is granted. ${ }^{89}$ In contrast, in the example of the hypothetical situation where environmental clauses were implemented, undertakings were affected based on the location of their headquarters. Because of the discriminatory criterion in the design of the tender, such a procedure would not be compliant with the EU public procurement directives (or in the case of contracts below thresholds, it would not be compliant with EU principles), so there would be a risk of undue economic advantage, ie State aid given to a certain tenderer. Therefore, the social clauses in this hypothetical case pass the acid test, but the environmental clauses fail it.

A case-by-case approach, with the due diligence of everybody concerned, is the only way governments, the Commission and the Court can secure compliance with all interconnected EU rules. As mentioned above, the acid test determines whether the contract was awarded according to public procurement rules and whether there was undue economic advantage, ie State aid granted. The acid test was chosen as a tool of detecting potential State aid since it relies on objective and firm rules of public procurement. ${ }^{90}$

In the following part of this paper, the authors address the $2014 \mathrm{di}$ rectives and the case law of the Court to establish whether something has changed in the relationship between EU public procurement and State aid rules. What are the risks of the 2014 directives if we know that they aim for a more flexible approach, increased use of negotiations in procedures, and wider application of environmental and social considerations? Is the acid test still valid?

\section{The new public procurement directives - a step forward for smart, sustainable and inclusive growth?}

As mentioned above, prior to the new public procurement directives, there was widely accepted consensus on the acid test with which it was

88 Eg, Decision in Case N142/2005 Low Carbon Car Grant Programme; Bacon (n 18) 28.

89 Assessment of the Commission of 30 May 2007, in Case N46/2007 Welsh Public Sector Network Scheme [C(2007) 2212 final].

90 See Bartosch (n 72) 551 
possible to determine whether there was undue economic advantage, ie State aid granted. The logic was that if the contract was awarded according to the public procurement rules, then there was (a rebuttable presumption that there was) no State aid. ${ }^{91}$ The point of interest in this section is to examine whether the test is still valid due to the reform (or lack of it) in public procurement rules as part of the 'Europe 2020' project and its impact on State aid rules. Therefore, the following main research aim of this paper will be analysed: Do the public procurement directives and the La Poste case create risks of infringing State aid rules.

To analyse the main research question, the authors discuss the following four topics:

1) When can the State participate in the market?

2) Links to the subject matter in public procurement procedures;

3) Negotiations in the public procurement procedure; and

4) Innovation partnership.

The authors take a critical approach to whether the project 'Europe 2020, a strategy for smart, sustainable and inclusive growth', is a smart way for achieving growth, even if it attains greater sustainability and inclusiveness.

The authors explore precisely these issues because 'Europe 2020' was one of the main influences in the drafting of the new public procurement directives. The EU's willingness to use public procurement rules as a means of achieving its societal and ecological goals can be seen throughout the new public procurement directives. However, the authors are worried that the reform motivated by 'Europe 2020' did a disfavour to the public procurement system, in particular from the perspective of the provisions on the link to the subject matter, on negotiations in the public procurement procedure, and on innovation partnership.

But what can also be seen in the new directives is the lack of coherence between State aid, its developing case law and public procurement rules. One of the main goals of 'Europe 2020' is growth. According to Tom Ginsburg, law matters for economic development. ${ }^{92}$ The authors believe that a coherent and a just legal system and the rule of law are vital for achieving growth. If the EU public procurement and State aid rules are not coherent, the EU will lose on its effectiveness in reaching its goals. Therefore, the authors also ask when the state can participate in the

\footnotetext{
91 Sànchez-Graells (n 74) 10; Bartosch (n 72) 551.

92 Tom Ginsburg, 'Does Law Matter for Economic Development? Evidence from East Asia' (2000) 34 Law \& Society Review 829 <http://home.uchicago.edu/ /tginsburg/pdf/articles/DoesLawMatterForEconomicDevelop ment.pdf $>$ accessed 22 April 2015.
} 
market to see if there is coherence between State aid rules and public procurement rules.

\subsection{When can the state participate in the market? One question, multiple answers}

In the EU, the public purchase of goods and services has been estimated to account for $16 \%$ of GDP, ${ }^{93}$ which shows the importance of public procurement rules to the EU economy. As previously mentioned, State aid rules are important because State aid may distort the dynamics of the competitive process. ${ }^{94}$ State aid may help perpetuate failed business models; it may reduce the incentive to compete; and it may create moral hazard by encouraging excessive risk taking. ${ }^{95}$

Thus, due to the importance of both EU public procurement and State aid rules, any new changes in public procurement rules motivated by 'Europe 2020' must respect the coherence of the EU legal system in general. It seems that the 'Europe 2020' project does not respect the coherence of EU law in an appropriate manner. More precisely, the authors believe that there is a shortcoming in the implementation of 'Europe 2020' in the field of EU public procurement rules and in the latter's relationship with EU State aid rules. This paper will go on to argue that unfortunately the EU has failed in this respect with the new public procurement directives. This was especially highlighted after the La Poste case of 3 April 2014.

In this landmark case, it was established that there was an implied and unlimited loan guarantee from the French State in favour of the French post office (La Poste) because of La Poste's status as a publicly owned establishment under French law and because La Poste could not be made subject to insolvency and bankruptcy procedures under ordinary law. ${ }^{96}$ According to two leading credit rating agencies, Fitch and Standard \& Poor's, such a guarantee was a determining factor for the credit rating. ${ }^{97}$ They held that the market takes account of credit ratings in assessing the credit to be granted to a given undertaking. ${ }^{98}$ Therefore, a rating which is better on account of a guarantee is an advantage because a guarantee enables the borrower, for example, to enjoy a lower interest rate or provide a lower level of security.

\footnotetext{
93 For more, see European Commission, 'Public Procurement'<http:/ / ec.europa.eu/trade/ policy/accessing-markets/public-procurement/> accessed 24 March 2015.

94 Bacon (n 18) 9.

95 ibid.

96 See François-Charles Laprévote, Charlotte Emin and Florine Coupé, 'The (French) Postman Rings Twice in Vain: The Court of Justice upholds of the GC's Judgment in La Poste' (2014) 4 ESTAL 735.

97 Case T-154/10 France $v$ Commission ECLI:EU:T:2012:452, para 106;

98 ibid.
} 
In order to determine whether a guarantee constitutes aid, it is necessary to apply the 'private investor test', ${ }^{99}$ in other words to determine whether the recipient received an economic advantage that it would not have obtained under normal market conditions. So, for the case involving the French post office and its State guarantee, the question is whether the French post office would have received such a guarantee under normal market conditions from any other private creditor. An undertaking can also obtain an advantage by not paying premiums for the guarantee because risk-carrying in the form of a guarantee should normally be remunerated by an appropriate premium under normal market conditions. ${ }^{100}$

As a consequence of undue benefits, there is a selective advantage to that undertaking in comparison to its competitors, and so the competition is distorted. There is also an effect on trade between MSs if the market was open for international competition, in accordance with the Mediaset case. ${ }^{101}$ All in all, such an implied and unlimited loan guarantee can constitute State aid that is incompatible with the internal market.

Therefore, every time there is such a guarantee from the State to an economic operator that forms part of the State or is under its ownership there is a high possibility that there is State aid. To summarise, the question is when can the State (or an economic operator that forms part of the State or is under the ownership of the State) participate in the market under State aid rules?

The State as an owner of a company can participate in the market only if the company is under such a legal form that the owner (in this case the State) is liable for the debts of its company only to the amount of its contributions and does not have to repay the debts of its company with its own property.

In the La Poste case, the European Commission requested the French authorities to make a conversion of the French post office to a public limited company in order to annul the implied and unlimited guarantee constituting State aid. ${ }^{102}$ Although the State was still the owner of the French post office after the conversion, there was no longer an implied and unlimited loan guarantee because the State could not be liable for the debts of La Poste because it was an owner of a public limited company. An owner of a company under such a legal form is liable for the

\footnotetext{
99 Case C-303/88 Italy v Commission ECLI:EU:C:1991:136, paras 21 and 22.

100 Commission Notice on the application of Articles 87 and 88 of the EC Treaty to State aid in the form of guarantees [2008] OJ C155, section 2.1.

101 Case C-403/10 P Mediaset v Commission ECLI:EU:C:2011:533, para 27.

102 Case C-559/12 P French Republic v European Commission ECLI:EU:C:2014:217, para
} 11 . 
debts of its company only to the amount of its contributions ${ }^{103}$ and does not have to repay the debts of its company with its own property.

Unfortunately, enterprises under which the State is liable for the debts of those enterprises exist in many MSs, in particular in the utility and railway sectors. ${ }^{104}$ Although little time has passed from the La Poste judgment, part of the blame for some enterprises violating State aid rules should be attributed to the lack of coherence in the EU legislation. Due to the La Poste case, one needs to check if there is coherence between the current EU State aid and public procurement rules and consult the new public procurement directives to answer the question about when the State (or an economic operator that forms part of the State or is under the ownership of the State) can participate in the market, ie in a public procurement procedure. There will be a completely different answer from the one deriving from a similar question relating to State aid rules.

According to the public procurement rules, the legal form of the tenderer is not important, and gives a diametrically opposed answer to the question about when an entity of the State can participate in a market, or for a market ${ }^{105}$ in the form of a public procurement procedure.

In 17 April 2014, two weeks after the judgement in the La Poste, the new public procurement directives came into effect. According to those directives a 'tenderer' 'means an economic operator that has submitted a tender'. ${ }^{106}$ An 'economic operator' 'means any natural or legal person or public entity or group of such persons and/or entities, including any temporary association of undertakings, which offers the execution of works and/or a work, the supply of products or the provision of services on the market'. ${ }^{107}$ Such a broad definition goes far beyond the limitation placed by the State aid rules on the issue of when an economic operator which forms part of the State can participate in a market, that is, in a public procurement procedure. This difference is most noticeable in the preamble to both of the new public procurement directives:

\footnotetext{
103 Jakša Barbić, Pravo društava, Društva kapitala, Svezak I. - Dioničko društvo; (6th edn, Organizator 2013) 15.

104 Valerie Guigue Koeppen, 'La Poste: Implied Unlimited State Guarantees Under the Loop of State Aid Law' (2014) 5 JECLP 548.

105 Competition in a market is a situation in which in an already established market, a certain number of competitors are competing between each other. While competition for a market is competition between a certain number of competitors which are competing between each other to win exclusive or partially exclusive access to a certain market. For example, if a public tender offers exclusive access to the market of collection of waste, then the competitors which apply for the public tender are competing for that market.

${ }^{106}$ Directive 2014/24/EU, art 2(10).

107 ibid, art 2(11).
} 
It should be clarified that the notion of 'economic operators' should be interpreted in a broad manner so as to include any persons and/or entities which offer the execution of works, the supply of products or the provision of services on the market, irrespective of the legal form under which they have chosen to operate. ${ }^{108}$ Thus, firms, branches, subsidiaries, partnerships, cooperative societies, limited companies, universities, public or private, and other forms of entities than natural persons should all fall within the notion of economic operator, whether or not they are 'legal persons' in all circumstances. ${ }^{109}$

Since, according to the public procurement rules the legal form of the tenderer is not important, this gives a diametrically opposed answer to the question about when an entity of the State can participate in a market or for a market in the form of a public procurement procedure. To make things more interesting, the Financial Transparency Directive gives a third answer to the same question.

According to the Financial Transparency Directive, the prerequisite for a public undertaking to participate in the market is to have a separate account from the public authority. ${ }^{110}$ Although such a rule is not contradictory to the public procurement rules, it can be misleading in the context of the La Poste case because the mere fact that a public undertaking has a separate account does not preclude the possibility of potential State aid. For instance, if the French post office in the La Poste case had a separate account from the public authority, it would still constitute State aid. Below, to summarise, the paper presents the three different answers to the question about when an economic operator which forms part of the State or is owned by the State can participate in a market or for a market in the context of a public procurement procedure and provides a possible solution to the problem.

a) State aid rules: when it is in a legal form in which the owner of the company is not liable with its property for the company's debts;

b) Public procurement rules: it can participate irrespective of the legal form;

\footnotetext{
108 Para 17 of the Recital to Directive 2014/25/EU of the European Parliament and of the Council of 26 February 2014 on procurement by entities operating in the water, energy, transport and postal services sectors and repealing Directive 2004/17/EC (Text with EEA relevance) [2014] OJ L 94/243.

109 Recital to Directive 2014/24/EU, para 14.

110 Art 1(2) of the Financial Transparency Directive 2004/109/EC of the European Parliament and the Council of 15 December [2004] OJ L390/38, amended by the Financial Transparency Directive 2013/50/EC of the European Parliament and the Council [2013] OJ L294/ 13.
} 
c) Financial Transparency Directive: when it has a separate account from the public authority.

The authors suggest that the public procurement rules and the Financial Transparency Directive should be changed at the first opportunity so that both contain the prerequisite that an economic operator which forms part of the State or is owned by the State should make a conversion to a legal form in which the owner of the company is not liable with its property for the company's debts in order to participate in the market or for the market. ${ }^{11}$ Although, the internal legal systems vary from MS to MS, each MS has a certain type of company under which the owner of the company is not liable with its property for the company's debts. ${ }^{112}$

Implementing these changes to the public procurement rules will help avoid State aid in the form of an implied and unlimited loan guarantee for all public undertakings that are participating in the public procurement procedure. It would also promote the basic principle of equal treatment and non-discrimination because undertakings linked to the State would not have a selective advantage from the very start of the tender process.

Likewise, if the Financial Transparency Directive were changed in this manner, it could achieve two things: a) it would be more coherent with the State aid rules; b) the public undertakings would also have separate accounts, since every undertaking that is a public limited company or a limited liability company or something similar has a separate account from the public authority. In this way, the Financial Transparency Directive would not lose its objectives, and the authors' suggestion would not have an effect on the area covered by the Financial Transparency Directive while it would promote adherence to State aid rules.

The authors believe that not only does it make sense to unify these rules, but also that this is in accordance with the basic principle of the rule of law and the principle of hierarchy of norms. Since the State aid rules are part of the Treaty on the Functioning of the European Union, it is part of EU primary law, which is the supreme source of law of the European Union, that is, it prevails over all other sources of law. It is at the apex of the European legal order. ${ }^{13}$ Given that the public procurement directives and the financial transparency directives are part of second-

\footnotetext{
111 Jakša Barbić, Pravo društava, Opći dio (3rd edn, Organizator 2008) 297.

112 W Zöllner, Gläubigerschutz durch Gesellschafterhaftung bei der GmbH (FS für Horst Konzen 2006) 999; Jakša Barbić, Pravo društava, Društva kapitala, Svezak I. - Dioničko društvo; (6th edn, Organizator 2013) 15.

113 'Primary law' < http://europa.eu/legislation_summaries/institutional_affairs/decisionmaking_process/114530_en.htm> accessed 10 August 2015.
} 
ary law, they should be in accordance with the primary source of law, in this case with State aid rules. One could say that the strategy for 'smart, sustainable and inclusive growth' does not appear to be so smart in this particular case.

\subsection{The link to the subject matter in public procurement procedures}

The EU public procurement directives are not concerned directly with what contracting authorities buy, but how they buy needed goods, works and services. ${ }^{114}$ They are concerned with defining the process which procedures can be used, what will the timeframe be for certain stages, what criteria can be set to define contracting authorities' preferences, etc. For this reason, the implementation of environmental and social considerations in public purchases is subject to certain rules. In this subsection, the development of the inclusion of non-economic criteria in public procurements is outlined. Further, the obligation to have a stable link to the subject matter for such criteria is also examined. In the conclusion, there is a critical take on the aim of the new directives to simultaneously encourage environmental and social policies in procurement procedures and to limit the role of the contracting authorities as market regulators.

In 1988, in the Beentjes case, the Court for the first time allowed public purchasers to acquire supplies and services with a higher societal value, upholding the requirement to employ long-term unemployed persons as one of the contract performance clauses. ${ }^{115}$ In 2000, 2002 and 2003, in the Nord-Pas-de-Calais and EVN and Wienstrom cases, the Court clarified its approach to environmental non-economic award criteria. ${ }^{116}$ These criteria cannot confer unrestricted freedom of choice on the contracting authority, they need to be expressly mentioned in the contract documents or the tender notice, they must comply with the fundamental principles of EU law, in particular the principle of non-discrimination,

\footnotetext{
${ }^{114}$ Even though, in the Green Paper on the modernisation of EU public procurement policy published in 2011, there was a proposal in support of the 'Europe 2020' policy objectives to 'impose on contracting authorities obligations on "what to buy". For example, by imposing mandatory requirements in regard of characteristics (eg a minimum level of recycling) or by setting targets (eg $70 \%$ of public purchases must be environmentally friendly). In the replies to the Green Paper, business, public authorities and MSs strongly opposed it, warning that such an obligation could lead to discrimination and restrict competition in procurement markets. The result would be fewer bidders and higher prices. Groups forming civil society were the only ones who supported this idea to a certain extent. Green Paper on the Modernisation of EU Public Procurement Policy: Towards a More Efficient European Procurement Market COM(2011) 41-42; ibid, Synthesis of Replies 15; cf Nicolas de Sadeleer, EU Environmental Law and the Internal Market (OUP 2014).

115 Case C31/87 Beentjes v Netherlands EU:C:1988:422.

${ }^{116}$ Cases C225/98 Commission v France (Nord-Pas-de-Calais) EU:C:2000:494; Concordia (n 37); C448/01 EVN AG \& Wienstrom GmbH v Austria EU:C:2003:651.
} 
and they must be linked to the subject matter. ${ }^{117}$ In the judgment of 2012 in the Max Havelaar case, the use of labels to certify organic and/or fair trade production as an award criterion was accepted. ${ }^{118}$

The tendency over time was to allow ever broader use of environmental and social considerations. The Court acknowledged that including non-economic criteria in purchases of goods, works and services would not undermine the basic aim of acquiring value for money. At the same time, MSs gained a valuable tool through which they could pass various horizontal policies and set an example of an environmentally and socially responsible buyer. Through these cases, the Court established a requirement that each non-economic criterion the contracting authority sets must be linked to the subject matter. For example, a requirement to reduce noise and pollution coming from the provision of urban bus transport in Concordia Bus was found to be linked to the subject matter. ${ }^{119}$ But rewarding the highest number of points for a tenderer able to supply the highest amount of renewable energy to consumers in excess of what was the contracting authority's consumption in the EVN and Wienstrom case was considered to be without a link to the subject matter. ${ }^{120}$ The procured good was electricity for the contracting authority's consumption, so a requirement for it to be from renewable sources can relate only to the amount needed for its consumption, but the terms of electricity supply from the same supplier for other consumers is outside the scope of the subject matter of the contract.

The judge-made requirement for a link to the subject matter was integrated into the 2004 directives, though it was not worded in the same way for each stage of the procurement procedure. Non-economical parameters in technical specifications had to be 'sufficiently precise to allow tenderers to determine the subject matter of the contract and to allow contracting authorities to award the contract'. ${ }^{121}$ Suitability criteria $^{122}$ related to economic and financial ability or technical and professional ability had to be 'related and proportionate to the subject matter of the contract'. ${ }^{123}$ A link to the subject matter is explicitly required for

\footnotetext{
117 Concordia (n 37) para 64.

118 Case C368/10 Commission v Netherlands (Max Haavelaar) EU:C:2012:284.

119 Concordia (n 37) para 65.

120 Case C448/01 EVN AG \& Wienstrom GmbH v Austria EU:C:2003:651, paras 67-68.

${ }^{121}$ In art 23 of the 2004 Directive, only environmental characteristics are mentioned, but the Court through its case law interpreted it generally to refer to non-economic characteristics. Directive 2004/18/EC of the European Parliament and of the Council of 31 March 2004 on the coordination of procedures for the award of public works contracts, public supply contracts and public service contracts [2004] OJ 1134/114 (Directive 2004/18/EC) art 23(3)(b).

${ }^{122}$ Corresponds to the selection criteria in the 2014 directives.

${ }^{123}$ Directive 2004/18/EC, art 44(2).
} 
all award criteria. ${ }^{124}$ And, finally, for the conditions for the performance of contracts, it states that '[c]ontracting authorities may lay down special conditions relating to the performance of a contract, provided that these are compatible with Community Law (...)'. ${ }^{125}$

In the Green Paper that preceded the modernisation of the public procurement directives in 2014, the Commission discussed loosening or even abandoning the link to the subject matter. It stated that such a move would be in favour of pursuing 'Europe 2020' policy objectives through public procurement, and would allow 'contracting authorities to influence the behaviour of undertakings regardless of the product or service purchased'. ${ }^{126}$ However, the Commission warned that the link guarantees purchases at the best price, so removing the focus from the subject matter of the contract might entail risks with regard to consistency with State aid rules. ${ }^{127}$

The final result of public consultations was, the authors believe, twofold. While formally strengthening the link to the subject matter, by advocating the application of the criteria related to any stage of the life cycle $^{128}$ 'from extraction of raw materials for the product to the stage of disposal of the product', ${ }^{129}$ the directives have allowed the widest use of environmental and social criteria so far.

The directives provide that technical specifications:

may also refer to the specific process or method of production (...) or to a specific process for another stage of its life-cycle even where such factors do not form part of their material substance provided that they are linked to the subject-matter of the contract and proportionate to its value and its objectives'. ${ }^{130}$

The wording for the selection criteria remained unchanged, demanding that all requirements are 'related and proportionate to the subjectmatter of the contract'. ${ }^{131}$ The same wording stayed for the award criteria as well, requiring a link to the subject-matter of the public contract in

\footnotetext{
124 ibid, art 53(1)(a).

125 ibid, art 26.

126 Green Paper (n 114) 39.

127 ibid

128 'Life cycle' means all consecutive and/or interlinked stages, including research and development to be carried out, production, trading and its conditions, transport, use and maintenance, throughout the existence of the product or the works or the provision of the service, from raw material acquisition or generation of resources to disposal, clearance and end of service or utilisation'. Directive 2014/24/EU, art 1.

129 Recital to Directive 2014/24/EU, para 97.

130 Directive 2014/24/EU, art 42(1).

131 ibid, art 58(1).
} 
question'. ${ }^{132}$ As regards contract performance clauses, to the existing 'relation to the performance of the contract', the new directives added an explicit requirement for a link to the subject matter. ${ }^{133}$

At the same time, the directives went further in defining what would be considered the link to the subject matter. In line with the recent development of the relevant case law of the Court, ${ }^{134}$ tending towards broader interpretation of the scope of the subject matter, the 2014/24 Directive held that

contracting authorities should be allowed to use award criteria or contract performance conditions relating to the works, supplies or services to be provided under the public contract in any respect and at any stage of their life-cycles from extraction of raw materials for the product to the stage of disposal of the product (...) even where such factors do not form part of their material substance. ${ }^{135}$

An extended view on the scope of the subject matter was also expressed in article 42 on technical specifications, again with reference to the various stages of the life cycle. ${ }^{136}$ The result of such a view is that anything that is included in the life cycle would thus be considered linked to the subject matter. ${ }^{137}$

In reaction to the new directives which opted for continued use of the link to the subject matter, Abbey Semple believes that under the 2014 directives there is a radical extension of the link to the subjectmatter requirement. ${ }^{138}$ She claims that the Green Paper overstated the importance of the link to the subject matter under the 2004 directives, describing this as 'a fundamental condition that has to be taken into account when introducing into the public procurement process any considerations that relate to other policies' which are applied 'throughout

\footnotetext{
132 ibid, art 67(2).

133 ibid, art 70.

${ }^{134}$ In 2012 the Court upheld the view of a broad link to the subject matter when it held in Max Havelaar that 'to require that the tea and coffee to be supplied must come from small scale producers in developing countries, subject to trading conditions favourable to them' fell within the social considerations permissible under art 26 of the 2004 Directive. See Case C368/10 Commission v Netherlands (Max Havelaar) EU:C:2012:284.

135 Recital to Directive 2014/24/EU, para 97 (emphasis added).

136 Directive 2014/24/EU, art 42(1).

${ }^{137}$ Marc Martens and Stanislas de Margerie, 'The Link to the Subject-Matter of the Contract in Green and Social Procurement' (2013) EPPPL 1, 17.

${ }^{138}$ Abby Semple, 'The Link to the Subject-Matter: A Glass Ceiling for Sustainable Public Contracts?' (2014) 12, available at: <http://papers.ssrn.com/sol3/papers.cfm?abstract_ id=2565051> accessed 26 September 2015 .
} 
the successive stages of the procurement process'. ${ }^{139}$ As outlined above, the subject-matter link explicitly appeared only in relation to the award criteria under the 2004 directives, and had only been referred to by the Court in this context. ${ }^{140}$ In essence, Semple claims that broader use of the link to the subject matter would narrow the application of social and environmental considerations.

The authors do not agree with such an opinion. On the contrary, they believe that in spite of the fact that the link has been nominally strengthened by its explicit mention in more of the provisions of the directive, its scope of application has in fact been broadened by introducing the notion of life cycle. The clear statement that non-economic criteria can relate to any stage of the life cycle extended what is considered to be the scope of the subject matter. Thus, as a consequence of the new directives, social and environmental considerations can be used more often in a public tender.

For example, the contracting authorities can now require that everyone from the original producer, intermediate supplier to the contracting authorities' supplier of certain goods behave in accordance with organic and fair trade requirements.

In conclusion, the consequence of the new public procurement directives' broad view on the link to the subject matter is that anything that is included in the life cycle would thus be considered linked to the subject matter. ${ }^{141}$ The authors believe that the European Union has taken the Niccolò Machiavelli logic which says that 'the goal justifies the means'. ${ }^{142}$ Although, such an approach might be useful for the 'Europe 2020' goals, unfortunately such logic is flawed in this case because: a) the means are not justified, and b) the goal could be reached by other less damaging means.

On the one hand, as this paper has already analysed in part 3, social and environmental considerations in a public tender can be a doubleedged sword. Such additional requirements could be misused in order to pick winners and losers of the public procurement procedure. The EU's choice of broadening the scope of the link to the subject matter and ipso facto widening the scope of social and environmental considerations which can be used in the public tender creates even more risk of discrimination than in the case of a narrower scope. Consequently, such a change in the public procurement rules leads to more risk of favouritism, distortion of competition and violation of State aid rules. The authors do

\footnotetext{
139 ibid.

140 ibid.

${ }^{141}$ Martens and de Margerie (n 137) 17.

142 Niccolò Machiavelli, The Prince (first published 1515, Bantam Dell 1996) 122.
} 
not agree with Semple who advocates a looser link to the subject matter. ${ }^{143}$ When the scope of the subject matter of the contract is debated, potential gains for sustainable development and social justice need to be weighed against the potential losses for other policies. Broader interpretation of the scope of the link to the subject matter can trigger misuse of non-economic requirements, which would infringe the rules of public procurement. Once they have been violated, the risk of State aid granted is plausible. To avoid this, the authors believe that the interpretation of the link to the subject matter needs to be narrower.

On the other hand, more effective tools for combating climate change and social injustice could be a larger amount of EU funds reserved for environment friendly and socially conscious projects, or additional EU legislation aimed at fulfilling the goals of 'Europe 2020' in both the public and the private sector. Despite the fact that the use of a larger amount of EU funds would bring more costs for the EU instead of relying on the MSs to spend their money on public procurement, it is the authors' belief that the problems could be tackled directly, rather than using defective solutions which compromise public procurement and State aid rules and the benefits which derive from compliance with those rules. Although the manifestation of the 'Europe 2020 strategy for smart, sustainable and inclusive growth' in this particular case might lead to more sustainability and inclusiveness, there are risks that public procurement and State aid rules will be compromised.

\subsection{Negotiations in the public procurement procedure}

The aim of public procurement rules is to secure fair competition among economic operators on the one hand, and the best use of taxpayers' money in public purchases on the other. For this reason, the underlying principle of public procurement is to treat economic operators equally and without discrimination, while acting in a transparent and proportionate manner. ${ }^{144}$ To guarantee a level European playing field, the award of public contracts below thresholds has to comply with the principles of the TFEU, and, for public contracts above thresholds, a national procedure compliant with the provisions of the procurement directives has to be applied. ${ }^{145}$

Under the 2004/18 and 2004/17 Procurement Directives, ${ }^{146}$ contracting authorities had open and restricted procedures which bore no

\footnotetext{
143 Semple (n 138).

${ }^{144}$ Directive 2014/24/EU, art 18(1).

145 Recital to Directive 2014/24/EU, para 1.

146 Directive 2004/18/EC, Directive 2004/17/EC of the European Parliament and of the Council of 31 March 2004 coordinating the procurement procedures of entities operating in the water, energy, transport and postal services sectors [2004] OJ 134/1.
} 
possibility of negotiations. ${ }^{147}$ Different variations of restricted procedures included negotiations, but were applicable only in a limited number of situations, where there could be a negotiated procedure with or without a prior publication of a contract notice. ${ }^{148}$ Through the procedure of a design contest, the jury selected a plan or a design. ${ }^{149}$ The new procedures introduced in the 2004 directives were a competitive dialogue, ${ }^{150}$ a dynamic purchasing system ${ }^{151}$ and an electronic auction. ${ }^{152}$

In 2010 in the Single Market Act, ${ }^{153}$ the European Commission announced its plan to modernise public procurement rules as part of the 'Europe 2020' strategy. The goal was to simplify the award of contracts and make the procedure more flexible to create an effective Europe-wide procurement market, which would at the same time support other policies and save billions of taxpayers' money. ${ }^{154}$ An additional goal was to increase cross-border procurement, which in 2009 accounted for only around $1.5 \%$ of all public contracts awarded. ${ }^{155}$

As part of the wide consultations that followed, in 2011 the Commission published the 'Green Paper on the modernisation of EU public procurement policy'156 (hereinafter: Green Paper) in which it detected the need for more flexibility in procurement procedures and broader use of negotiations in the procedures. In response to the questions posed in the Green Paper, the majority of interested stakeholders, namely businesses, MSs, public authorities and even legal experts, supported the suggestion to allow more negotiation or to generalise the use of the negotiated proce-

\footnotetext{
147 ibid, art 28.

148 ibid, arts 30-31.

149 ibid, arts 66-74.

150 ibid, arts 28-29.

${ }^{151}$ A two-stage process for whose setting up and subsequent award of contracts contracting authorities use solely electronic means. Following the rules of the open procedure, all economic operators who satisfy the selection criteria and are not subject to some of the exclusion grounds must be admitted to the dynamic purchasing system. They do not need to demonstrate suitability and capability each time they wish to compete for a public contract. In the second stage, authorities invite economic operators to bid for the specific contract. Directive 2004/18/EC, art 33.

152 After an initial full evaluation of the tenders, an electronic device for the presentation of new prices, revised downwards, and/or new values concerning certain elements of tenders, is used to rank tenders using automatic evaluation methods. Consequently, contracts having intellectual performances as their subject matter may not be the object of electronic auctions. Directive 2004/18/EC, art 54.

153 Communication from the Commission to the European Parliament, the Council, the Economic and Social Committee and the Committee of the Regions, Towards a Single Market Act for a highly competitive social market economy: 50 proposals for improving our work, business and exchanges with one another' COM (2010).

154 ibid 15.

155 ibid.

156 Green Paper, Synthesis of replies (n 114) 10.
} 
dure with prior publication of a contract notice. ${ }^{157}$ They argued that with an increased margin for negotiation, the contracting authorities could procure goods, works and services that were more fitting to their actual needs. The only stakeholders opposing this proposition were civil society and, to a certain extent, SME representatives. ${ }^{158}$

However, from the initial advocacy in the Green Paper for more negotiation, the Commission acknowledged that negotiated procedures increase the risk of favouritism and give rise to overly subjective decisions due to the greater discretion enjoyed by contracting authorities. ${ }^{159}$ The Commission explicitly stated that negotiated procedures would make it harder to detect possible grants of State aid. A clear majority of stakeholders stated that they were indeed aware of the possible negative consequences in terms of abuse, transparency and discrimination. ${ }^{160}$

As mentioned above, the belief that a procurement procedure compliant with the directives ruled out the possibility of undue economic advantage was based on the 'rigidity' of public procurement rules. The behaviour of the contracting authority was strictly monitored, so the potential to favour certain economic operators, especially domestic ones, was minimised. With the new directives, with the aim of improving the outcomes of the procurement procedures, the discretion enjoyed by the contracting authorities grew considerably. General availability and grounds for the use of negotiated procedures widened, and, in the opinion of the authors, so did the risk of granting State aid incompatible with the internal market.

The new directive kept the basic open and restricted procedures, but made it easier for the contracting authorities to choose from the two options. Stating that 'MSs shall provide that contracting authorities may apply open or restricted procedures', ${ }^{161}$ the directive removed the previous right of MSs to decline to use one of these procedures in their national systems, or to place restrictions when both of these procedures were available, for example restricting use for certain procuring entities or for certain types of procurement. ${ }^{162}$ In the authors' view, by doing this, the new directive made a somewhat dubious move. While trying to assure that every contractor can select the procedure that suits it best, the new directive deprived MSs of the right to intervene in the process. Even if an MS believes that for certain authorities, sectors or types of public

\footnotetext{
157 Green Paper (n 114).

158 ibid.

159 ibid.

160 ibid 11.

161 Directive 2014/24/EU, art 26(2)

162 Sue Arrowsmith, The Law of Public and Utilities Procurement: Regulation in the EU and UK (3rd edn, vol 1, Sweet \& Maxwell 2014) para 7 - 07.
} 
contract it would be more beneficial to set the conduct of an open procedure as the general rule in order to enhance transparency, objectivity and public support, it is now not allowed to do so. ${ }^{163}$

There are three more competitive procedures provided in the 2014 directives, two of which already existed before: competitive dialogue and competitive procedure with negotiations (previously named negotiated procedure with a notice), and innovation partnership as the third one, intended for the development and purchase of innovative goods, works and services. The risks of the latter will be discussed in the following subsection.

The main difference of these procedures in contrast to the restricted procedures is that after a contracting authority invites a certain number of economic operators that request to participate, their submitted tenders are subject to subsequent negotiations. ${ }^{164}$ In the case of competitive dialogue, after being invited, the tenderers automatically enter into dialogue with the authorities to identify the means best suited to their needs. ${ }^{165}$ These procedures, due to the higher discretionary margin of the contracting authorities, were available only on limited grounds.

As a result of public consultations, the use of negotiated procedures was allowed only in certain situations. But both for competitive dialogue and a competitive procedure with negotiations, two similar (and rather important) changes occurred.

First, as with the open and restricted procedure, the new directive stated that 'MSs shall provide that contracting authorities may apply (...) in the following situations', ${ }^{166}$ with the consequence that governments cannot decline to incorporate these procedures in their national systems, nor can they restrict their use at all in the situations listed in article 26. ${ }^{167}$ By limiting MSs' discretion to regulate, this provision increases the discretion of the contracting authorities. Whether or not this is at the cost of transparency and non-discrimination remains to be seen. ${ }^{168}$

Second, the permitted grounds for the use of these procedures widened, and, in addition, became the same for both competitive dialogue and a competitive procedure with negotiations. ${ }^{169}$ Paragraph 42 of the

\footnotetext{
${ }^{163}$ In line with this reasoning, see the discussion in Arrowsmith (n 162) paras $7-07,8-09$, $9-19$.

164 Directive 2014/24/EU, art 29.

165 ibid, art 30.

166 ibid, art 26(4).

167 Arrowsmith (n 162) paras 8-09, 9 - 19.

${ }^{168}$ In line with this reasoning, see the discussion in Arrowsmith (n 162) paras $7-07,8-09$, $9-19$.

${ }^{169}$ For a comparison, see articles 29 and 30 of Directive 2004/18/EC and article 26(4) of Directive 2014/24/EU.
} 
Recital to the 2014 Directive suggests that, based on previous experience, greater use of these procedures is also likely to increase participation in cross-border tenders. ${ }^{170}$ Arrowsmith claimed that this is a rather questionable assumption, because a higher rate of cross-border tenders is probably the result of the nature of the procurement (often high-value and complex) and not the nature of the procedure used. ${ }^{171}$ The authors agree, claiming that the Commission in its reasoning mixed up cause and effect. The value of the awarded contract is a cause and the nature of the procedure is an effect.

The authors believe that with the policy shift towards a more flexible choice of procedures and a wider use of negotiated procedures, the viability of the 'public procurement - State aid' test comes into question. The presumption from the case of the Welsh Public Sector Network Scheme that the conduct of a procurement procedure compliant with the EU public procurement directives and suitable for achieving the best value for money means that no State aid was granted during the process ${ }^{172}$ may not hold such firm support as it did prior to the new directives. ${ }^{173}$ An increased scope for negotiations that increases the discretion enjoyed by the contracting authorities bears the risk of public contracts being awarded on an overly subjective criterion, which in turn would make it harder to prove that the resulting contract did not involve State aid. ${ }^{174}$

Two goals were set in front of the modernisation of public procurement rules as part of the 'Europe 2020' strategy, as a market-based instrument which would be used to achieve its objectives: ${ }^{175}$ to ensure the most efficient use of public funds and to keep procurement markets open EU-wide. ${ }^{176}$ Applying the acid test was a way of checking whether undue economic advantage, which in its core is diametrically opposed to these goals, was granted in the process. By restricting the discretion of MSs in regulating national procurement procedures on the one hand, and widening the scope of negotiations for contracting authorities on the other, the new directives brought the consensus concerning this test into question.

In a certain number of cases, procurement procedures will be compliant with the public procurement directives, but will this ensure the

\footnotetext{
${ }_{170}$ Recital to Directive 2014/24/EU, para 42. This is a finding of the evaluation report that led to the 2014 directives. See European Commission, Commission Staff Working Paper, 'Evaluation Report: Impact and Effectiveness of EU Public Procurement Legislation' SEC (2011) 853 final.

${ }^{171}$ See Arrowsmith (n 162) paras 8-18.

172 ibid.

${ }^{173}$ For a similar discussion on this subject, see Sànchez-Graells (n 74)

174 Green Paper (n 114) 15; Sànchez-Graells (n 74) 12

175 Green Paper (n 114) 3.

176 ibid.
} 
best value for money and will it rule out the possibility of State aid? The authors believe that it is debatable whether best value for money will be achieved. Moreover, they are convinced that compliance with the new public procurement directives cannot rule out the possibility of State aid. Although it was also not ruled out entirely before the new directives, it seems that it is even truer now after the enactment of the new directives that they cannot rule out the possibility of State aid. If the importance of State aid rules is taken into account, as well as the benefits of complying with them, the authors believe that in this particular case the new public procurement directives are a step back for growth in the 'Europe 2020 strategy for smart, sustainable and inclusive growth'.

\subsection{Innovation partnership}

The 2014 directives introduced a new award procedure, innovation partnership. It is designed for situations in which the contracting authority identifies the need for an innovative product, service or works, because its needs 'cannot be met by purchasing products, services or works already available on the market'. ${ }^{177}$ It comprises development of an innovative good, service or work as a first phase, and the subsequent purchase of the result as a second. ${ }^{178}$ In the wording of article 26, this procedure must also be available to contracting authorities, and cannot be subject to any restrictions from the MSs. ${ }^{179}$ Any interested economic operator may submit a request to participate, but only those invited by the contracting authority may participate in the procedure. ${ }^{180}$ Contracting authorities negotiate the initial and all subsequent tenders submitted by the participants, except for the final tender, but ' $[t]$ he minimum requirements and the award criteria shall not be subject to negotiations' ${ }^{181}$ Negotiations can be conducted in successive stages in order to gradually reduce the number of tenders to be negotiated. ${ }^{182}$

It is obvious that this kind of restricted, negotiated procedure, with the possibility of reducing the number of candidates and the vague subject matter of the contract, bears the risk of anti-competitive, subjective and discriminatory behaviour. It has indeed raised a number of issues, such as those concerned with grounds, structure, intellectual property rights (hereinafter: IPR), confidentiality and State aid. ${ }^{183}$

\footnotetext{
177 Directive 2014/24/EU, art 31(1).

$178 \mathrm{ibid}$, art 31(2).

179 ibid, art 26(3).

$180 \mathrm{ibid}$, art 31(1).

181 ibid, art 31(3).

182 ibid, art 31(5).

183 Pedro Telles, 'Public Contracts Regulations 2015 - Regulation 31'<http://www.telles. $\mathrm{eu} / \mathrm{blog} / 2015 / 4 / 9 /$ public-contracts-regulations-2015-regulation-31> accessed 23 April 2015.
} 
Sànchez-Graells expressed doubts about the ability of contracting authorities to conclude that there is a 'need for an innovative product, service or works that cannot be met by purchasing products, services or works already available on the market'. ${ }^{184}$ It is unlikely that the contracting authorities themselves would be able to identify something that has not been previously identified by the market, or that the adaptation of existing products or services is not possible. ${ }^{185}$

An improper assessment of the situation by the contracting authority is then followed by a highly discretionary procedure rather than other 'traditional' competitive public procurement procedures. Such a situation would be compliant with the directives, but the authors believe it would undeniably create unnecessary risks and costs for both contracting authorities and economic operators. As proposed in subsection 3.2 (on the link to the subject matter), additional EU funds reserved for fulfilling the goals of 'Europe 2020' or EU legislation aimed directly at the targeted objectives of 'Europe 2020', at least in this particular case, would be more useful than using defective solutions.

Once the innovation partnership is decided on, there are a few ways in which competition can be disrupted. Pedro Telles calls them 'pieces of the Trojan horse puzzle'. ${ }^{186}$

One of the ways is the right of the contracting authority to 'decide to set up the innovation partnership with one partner or with several partners conducting separate research and development activities'. ${ }^{187}$ This is the only procedure which can run from the start to the end with one economic operator. ${ }^{188}$ Therefore, even though article 31 of the Innovation Partnership refers to article 65 of the Directive with regard to limiting the number of candidates to be invited (including the obligatory minimum number) ${ }^{189}$ the first provision acts as a special rule towards the latter

${ }^{184}$ Directive 2014/24/EU, art 31(1); Albert Sànches-Graells, 'Innovation Partnerships under Reg 31 Public Contracts Regulations 2015 <http://howtocrackanut.blogspot. com/2015/04/innovation-partnerships-under-reg-31.html> accessed 23 April 2015.

185 Sànches-Graells offers a curious assessment of the position of economic operators under this presumption. He notices that the pool of potential contractors will be reduced only to those who also believe a solution is non-existent and to those 'willing to play along', who will confirm the authorities' improper assessment and then offer an already existing solution by faking or duplicating the innovation process. Sànches-Graells (n 184).

186 Telles (n 183).

187 Directive 2014/24/EU, art 31(1) (emphasis added).

188 Telles (n 183)

189 'The contracting authorities shall indicate, in the contract notice or in the invitation to confirm interest (...) the minimum number of candidates they intend to invite and, where appropriate, the maximum number. In the restricted procedure the minimum number of candidates shall be five. In the competitive procedure with negotiation, in the competitive dialogue procedure and in the innovation partnership the minimum number of candidates shall be three. (...) However, where the number of candidates meeting the selection criteria 
as a general rule. ${ }^{190}$ In spite of the obligation of the contracting authority to treat economic operators equally, ${ }^{191}$ due to such wording there is the potential to restrict competition and favour certain economic operators.

The second way in which a contracting authority and/or his/her partner may misuse innovation partnership can be found in the vaguely expressed provision of the directive regarding the interrelationship between the value of the investment and the duration of the partnership. ${ }^{192}$ Article 31(7) of the 2014/24 Directive states:

The contracting authority shall ensure (...) the duration and value of the different phases reflect the degree of innovation of the proposed solution (...). The estimated value of supplies, services or works shall not be disproportionate in relation to the investment required for their development.

Under wording like this, many costs can be attributed to the investment required for development (for example, examining the available solutions, modification and adaptation of the necessary tools, etc), and the time needed to conduct each phase and for research, development, manufacturing and supply is hardly estimated by anyone outside the partnership. ${ }^{193}$ As Telles puts it: 'a resulting partnership can last for a long time before anyone can start asking questions'. ${ }^{194}$

Another major issue associated with the innovation partnership is its compatibility and potential interference with the '2014 Framework for State aid for research and development and innovation' (hereinafter: R\&D\&I). ${ }^{195}$ The potential to circumvent the latter set of rules with the use of innovation partnership has been discussed among academics. ${ }^{196}$

and the minimum levels of ability as referred to in Article 58(5) is below the minimum number, the contracting authority may continue the procedure by inviting the candidates with the required capabilities'. Directive 2014/24/EU, art 65(2).

190 Telles (n 183).

${ }^{191}$ Directive 2014/24/EU, art 18.

192 Telles (n 183).

193 ibid.

194 ibid.

195 Communication from the Commission - Framework for State aid for research and development and innovation [2014] OJ C198/1 (Framework for R\&D\&I State aid): 'The EU's R\&D\&I state aid rules are set out in two complementary texts: the new General Block Exemption Regulation (GBER) sets out the conditions under which state aid may be granted without prior notification to the Commission. The new Framework, in turn, sets out the criteria under which the Commission will assess R\&D\&I aid measures which have to be notified by MSs because they have a higher potential for distorting competition'. European Commission, 'Commission Adopts New Rules Facilitating Public Support for Research, Development and Innovation’ (Press Release, 21 May 2014) <http://europa.eu/rapid/pressrelease_IP-14-586_en.htm> accessed 24 November 2015.

196 Sànches-Graells (n 184). 
To help reach the targets of the 'Europe 2020 Strategy for smart, sustainable and inclusive growth', the Commission worked on the State Aid Modernisation package. ${ }^{197}$ One of the key components of this package is the R\&D\&I which sets out the conditions under which MSs can grant State aid to companies to carry out R\&D\&I activities, but at the same time limiting distortions in the Single Market. ${ }^{198}$

The Framework allows public procurement of research and development services and considers it to be, in principle, in compliance with article 107 TFEU, ie not granting State aid incompatible with the internal market in two cases that are not two cumulative conditions:

[a]s long as an open tender procedure for the public procurement is carried out in accordance with the applicable directives (..); 199 and

[i]n all other cases (...) where the price paid for the relevant services fully reflects the market value of the benefits received by the public purchaser and the risks taken by the participating providers, when a number of conditions are cumulatively met; ${ }^{200}$ one of which is relevant to mention. ${ }^{201}$

The procurement does not give any of the participating providers any preferential treatment in the supply of commercial volumes of the final products or services to a public purchaser in the MS concerned.

The innovation partnership procedure, as discussed above, is not an open but a restricted and a negotiated procedure with the potential to favour one economic operator from the start to the end. Thus, it cannot

197 The modernisation of State aid policy focused on facilitating aid targeted at market failures and the objectives of common European interest. Part of the focus was also on cases with the biggest impact on the internal market, streamlining rules and taking faster decisions. European Commission, Press Release (n 195); for more, see Erika Szyszczak, Research Handbook on European State Aid Law (Edward Elgar 2011).

198 European Commission, Press Release (n 195).

199 Framework for R\&D\&I State aid (n 195) para 32.

200 Others are: a) the selection procedure is open, transparent and non-discriminatory, and is based on objective selection and award criteria (...); b) the envisaged contractual arrangements describing all rights and obligations of the parties (...) are made available to all interested bidders in advance of the bidding procedure. Framework for R\&D\&I State aid (n 195) para 33.

201 Sànches-Graells also discusses the fourth condition requiring that: a) all results that do not give rise to IPR may be widely disseminated, for example through publication, teaching or contribution to standardisation bodies in a way that allows other undertakings to reproduce them, and any IPR are fully allocated to the public purchaser; or b) any service provider to which results giving rise to IPR are allocated is required to grant the public purchaser unlimited access to those results free of charge, and to grant access to third parties, for example by way of non-exclusive licences, under market conditions. However, the problematics of IPR go beyond the scope of this paper. Sànches-Graells (n 184). 
fit under the first condition. ${ }^{202}$ As regards the alternative case, innovation partnership, by definition, including the development and subsequent purchase of the procured good, work or service, does create "preferential treatment for the supply of the results of the innovation'. ${ }^{203}$ In the opinion of the authors, repayment of all investment costs eliminates most of the risk for the economic operator and creates preferential treatment for the operator's output on the market.

In conclusion, there is the possibility of anti-competitive behaviour of the contracting authority in the short-term, but also the potential for deferred anti-competitive effects once the procured subject enters the commercial market. ${ }^{204}$ When the product, or a certain solution for a work or a service, finds itself in competition with products that were developed and placed on the market without any intervention of the MS in any form, there are risks of anti-competitive effects.

In spite of the lack of compatibility with the provisions of the Framework, the contracting authority may continue with the award of the innovation partnership according to paragraph 34, stating that if the conditions in point 33 are not fulfilled, MSs may rely on an individual assessment of the terms of the contract (...) but without prejudice to the general obligation to notify R\&D\&I aid pursuant to Article 108(3) of the Treaty'. ${ }^{205}$ This would mean an obligation to inform the Commission and to stay with the procedure until the Commission's final decision declaring that such a plan is compatible with the internal market. ${ }^{206}$

Given the above, innovation partnership can be considered as the first type of Public Private Partnership (hereinafter: PPP) regulated by European public procurement legislation. In PPP, partners can have various shares, and, accordingly, different rights and obligations. This would be the case in particular if the participation of the MS is led by considerations other than commercial ones, so that it would be willing to accept less favourable terms. Nevertheless, in public - private cooperation through the innovation partnership, in line with the acid test and the 'market economy investor/consumer principle', PPP may create undue economic advantage for the private partner when no market operator would accept participating on the same terms as the public partner. The

\footnotetext{
202 ibid.

203 ibid.

204 Sànchez-Graells (n 74) 16.

205 Framework for R\&D\&I State aid (n 195) para 34.

206 'The Commission shall be informed, in sufficient time to enable it to submit its comments, of any plans to grant or alter aid. If it considers that any such plan is not compatible with the internal market having regard to Article 107, it shall without delay initiate the procedure provided for in paragraph 2. The MS concerned shall not put its proposed measures into effect until this procedure has resulted in a final decision'. Art 108(3) TFEU.
} 
terms and conditions governing investments and the subsequent handling of the results are not equal for the public and private partner. This, for example, is the case when the latter is guaranteed a certain rate of return, or when the conditions of debts and loans are all considerably more favourable for the private partner. ${ }^{207}$

As explained above, not every PPP (or, for that matter, innovation partnership) with uneven terms will contain disguised State aid. ${ }^{208}$ This is especially the case if the acid test is applied with the presumption that the awarding of an innovation partnership compliant with the directives rules out State aid incompatible with the internal market. Even in this situation, shortcomings in the innovation partnership as a procurement procedure discussed previously remain unaltered, and thus must be borne in mind.

Research and innovation play a key role in the 'Europe 2020' strategy, and public authorities are encouraged to make the best strategic use of public procurement to spur innovation. ${ }^{209}$ Public purchase oriented towards innovative products and services is seen as a way to improve the quality and efficiency of public services at a time of budget constraints'. ${ }^{210}$ For these reasons, the new directives have introduced considerable flexibility in the choice of competitive dialogue and negotiated procedures, and at the same time have created the innovation partnership procedure.

But, in the authors' view, the legal set up of innovation partnership has too many weak spots to be trusted. The inability of the MS to place any restrictions on the use of this procedure unreasonably restricts its right to regulate the behaviour of bodies governed by public law. Access to probably the most complex procedure for potentially inexperienced authorities is wide open, which can result in something very different from the intended gain of value for money. High levels of discretion enjoyed by the contracting authority, particularly facilitated by the right to run an innovation partnership from start to finish with a single supplier, bear a considerable risk of anti-competitive behaviour. The negative effect of this practice might be observed not just in the short term, as wrongful or at least deficient behaviour of the contracting authorities, but also in the long term, in regard to the relationship between those solutions and the ones created solely on the market without public interference.

With the aim of encouraging innovative solutions, which would in turn bring about industrial and overall growth, the new directives, in

\footnotetext{
${ }^{207}$ For a broader discussion of PPP and how to ensure its compliance with State aid rules, see Nicolaides and Schoenmaekers (n 73).

208 ibid 59.

${ }^{209}$ Recital to Directive 2014/24/EU, para 47.

210 Green Paper (n 114) 44.
} 
the authors' view, 'rushed' with procedures like innovation partnership. The vague and incoherent provisions of the directive could be (too) easily circumvented by the public sector, intentionally or unintentionally, resulting in the inappropriate use of taxpayers' money. Hence, the authors believe that the directives have their shortcomings.

The Court of Justice of the European Union would have to introduce more rigid limitations in its interpretation of the provisions of the directive concerned with the innovation partnership. Although the question is whether or not there is room for such an interpretation in the directive itself, the authors believe that such more rigid limitations in the interpretation of the provisions of the directive are needed both to prevent potential misuse and to ensure the safe and useful application of the innovation partnership procedure. The authors believe that in this case the new public procurement directives are also a step back for growth in the 'Europe 2020 strategy for smart, sustainable and inclusive growth'.

\section{Conclusion}

The EU has rightly identified the importance and the far-reaching significance of public procurement rules. There is no better argument for such a conclusion than the fact that the EU has decided to use the new public procurement directives as one of the key means to achieve the goals of 'Europe 2020 for smart, sustainable and inclusive growth'. Two main goals are set with the modernisation of the general and utilities directives: to ensure value for money in public purchases and to use public procurement procedures to support different policies.

The authors have examined the impact of the 'Europe 2020' strategy on the new public procurement directives. Further, they have taken a critical approach towards the provisions of the 2014 directives, and discussed coherence with the rules prohibiting State aid that is incompatible with the internal market.

Unfortunately, it appears that what you gain somewhere, you lose elsewhere. Although the impact of 'Europe 2020' on public procurement rules may be beneficial for enhancing the use of environmental and social considerations, it may create the risk of discrimination and have a negative effect on the interrelationship of public procurement and State aid rules.

While the prohibition of discrimination is one of the main principles of EU law governing every policy, the State aid rules from the TFEU are important to ensure that competition in the EU internal market is not distorted by the intervention of one MS in favour of an undertaking. In connection with the public procurement rules, State aid rules make sure 
that contracting authorities go for 'value for money' in their purchases, and that the public procurement procedure is open and fair at the entire EU level.

The authors are critical of the new public procurement directives because they believe that a more flexible approach to negotiation procedures and innovation partnership, with the consequence of higher discretion enjoyed by the contracting authority, leads to a higher risk of unequal treatment and the opportunity to grant disguised State aid. Moreover, the authors point to the lack of coherence between the public procurement directives and the developing case law on State aid rules. The inability of 'Europe 2020' and the modernised directives to ensure coherence among the different branches of the legal system endangers not just the rule of law, but may also be counterproductive to growth, as one of the aims.

The issue of broadening the scope of the subject matter is a perfect all-in-one example: although it allows broader implementation of environmental and social considerations, at the same time it opens the way for discrimination and is potentially detrimental to State aid rules.

In light of the risks of the new public procurement directives and the developing case law concerning State aid, highlighted in the landmark case La Poste, the authors believe that the compliance of contracting authorities with public procurement rules can no longer presume that no State aid was granted. The acid test has turned sour.

Doing everything that we can to solve problems and using every tool available to achieve certain goals may be tempting, especially when the goals are nothing but noble. But the road to hell is paved with good intentions. The implementation of 'Europe 2020' in the new public procurement directives is a good example of how certain measures may bring unintended harm. There is a plethora of possible means for smart, sustainable and inclusive growth, and the EU should choose them cautiously so as not to cause a negative trade-off as regards its other policies and rules. The authors advocate great caution to ensure the proper and effective application of the 2014/24 and 2014/25 directives and to avoid their (intentional or unintentional) misuse. 